\title{
Frequência alélica do SNP c.1431G>A no gene da TYR responsável pelo albinismo em búfalos (Bubalus bubalis) no Brasil
}

Pedro N Bernardino, Aline FA Martins, Alexandre S Borges, José P Oliveira-Filho

Faculdade de Medicina Veterinária e Zootecnia, Universidade Estadual Paulista (Unesp), Botucatu, SP, Brasil

*Autor correspondente

e-mail: zefilho@fmvz.unesp.br

\section{Resumo}

O Albinismo Óculo-cutâneo (OCA) é uma enfermidade hereditária que acomete humanos e animais, causada, sobretudo, por mutações no gene da tirosinase (TYR). Em búfalos, a OCA tem caráter autossômico recessivo e pode ser causada pelo SNP (polimorfismo de nucleotídeo único) c.1431G>A, no gene da TYR, que produz uma proteína truncada afuncional incapaz de sintetizar a melanina. Consequentemente, os animais afetados apresentam ausência de pigmentação dos pêlos, pele, chifres, cascos, mucosas e íris, além de fotofobia. Embora o fenótipo de animais com OCA seja facilmente percebido, animais heterozigotos (OCA/N) não serão distinguidos dos demais a não ser que testes moleculares sejam realizados. Nesse propósito, o objetivo deste estudo foi verificar a frequência do alelo c.1431G>A em uma amostragem de 315 búfalos (Bubalus bubalis), fenotipicamente normais, provenientes de oito propriedades localizadas nos estados do Pará ( $\mathrm{n}=2)$, Paraná $(n=2)$, Rio Grande do Sul $(n=1)$ e São Paulo $(n=2)$. 0 DNA purificado de amostras de pêlo, sangue ou sêmen dos animais foi utilizado em PCR que amplificava a região gênica contendo a mutação responsável pela OCA. Em seguida, a genotipagem dos animais foi realizada a partir da análise dos eletroferogramas e sequências obtidas do sequenciamento direto desses produtos de PCR. Cerca de 3,5\% (11/315) dos animais eram heterozigotos para o SNP c.1431G>A e o os demais 96,5\% (304/315) não possuíam alelos mutados (Wild Type). Os 11 animais heterozigotos eram provenientes de duas propriedades localizadas no estado do Pará (2/12 e 3/39) e de uma localizada no estado do Rio Grande do Sul (6/111). Búfalos com OCA estão sujeitos, em maior intensidade, a lesões ocasionadas pela ação direta dos raios solares na pele e olhos despigmentados. Particularmente em regiões tropicais como o Brasil, este defeito provoca dificuldade no manejo e prejuízos econômicos decorrentes dos tratamentos destas lesões e da queda da produção de animais criados extensivamente, os quais diminuem a ingestão de alimentos por ficarem parte do tempo se protegendo da incidência solar. Embora a frequência alélica $(1,75 \%)$ do SNP c.1431G>A na população 
estudada possa parecer pequena, chama atenção a detecção deste SNP responsável pela OCA em rebanhos localizados em estados geograficamente distantes. Portanto, os resultados deste estudo permitem inferir que o conhecimento do genótipo, sobretudo de reprodutores, possibilitaria a seleção dos acasalamentos com o objetivo de se evitar o nascimento de animais clinicamente afetados por OCA e, desta forma, minimizar os prejuízos econômicos decorrentes desta enfermidade.

Agradecimentos: à Coordenação de Aperfeiçoamento de Pessoal de Nível Superior (Processo 23038.007227/2012-04) pelo financiamento da pesquisa e à Fundação de Amparo à Pesquisa do Estado de São Paulo (2015/23569-4) pela concessão de bolsa de iniciação científica. 